Татјана Н. ЈОВИЋЕВИЋ ${ }^{*}$

Институт за књижевност и уметност Београд
Оригинални научни рад

Примљен: 19. 11. 2016.

Прихваћен: 10. 02. 2017.

\title{
ЕСЕЈИСТИЧКИ ДИСКУРС И КЮИЖЕВН(ОКРИТИЧК)А МИСАО ЛАЗЕ КОСТИЋА
}

\begin{abstract}
Рад анализира текст Костићевог есеја „Ромео и Јулија” (1866) са становишта примењених интерпретаторских поступака, те језика и/или дискурса којима/унутар којих су формулисани. Посебна пажња посвећена је централној метафори „духа и блата”, на почетку уведеној да означи супротстављене силе на којима се темељи Шекспиров/шекспировски свет, да би потом била употребљена као фактор повезивања и уланчавања сегмената текста посвећених разматрању других питања, у вези са којима се њено значање преноси на друга поља.
\end{abstract}

Кључне речи: Лаза Костић, Шекспир, Ромео и Јулија, дискурс, Британија, постколонијална критика, „Омер и Мерима”.

Дефинисање есеја суштински је везано управо за одређивање дискурca у коме настаје, те је тако и историјат његовог промишљања у највећој мери расправа о особеностима текстуализације утисака, идеја и асоцијација у чијим се оквирима разматра „предмет” есеја, тј. феномен коме је он посвећен. И све то, наравно, далеко пре него што је термин „дискурс” скован и прихваћен у данашњем комплексном (наратолошком/семантичком/идеолошком) значењу.

Основни постулати модерне теорије есеја, од њених почетака у раном 20. веку, успостављени су истицањем његових минус-својстава, што је испољено већ у премиси да је есејистичко писање окарактерисано одсуством „сврховитости” (тј. тежње ка изградњи обухватног филозофског, естетичког или сл. система), и то без обзира да ли је ово виђено као недостатак, као у Лукачевој (Лукач (1910) 1973) тези да је есеј „вапај за изгубљеним тоталитетом", или да се, као нешто доцније код Адорна (Адорно (1955) 1996), управо ово својство сматра отвореном могућношћу есеја. И бројни други аутори, који питању есеја нису приступали са оваквог „онтолошког”, већ са становишта анализе посебних аспеката есејистичког текста, описивали су га

\footnotetext{
*tbjovicevic@gmail.com
} 
управо преко онога што га на методолошком, терминолошком, језичко-стилском плану разликује од текста филозофске/естетичке/научне расправе или академске књижевне/уметничке критике схваћених као стандард писања о заједничким преокупацијама.

Немогућност да се есеј на поетичком и морфолошком плану диференцира као жанр довела је до тога да се о њему примарно расправља са становишта његовог језика (у лотмановском и женетовском смислу), односно - дискурса. Тежња да се тај дискурс формулише може се кретати у простору размишљања о есеју као облику који стоји између књижевног и (у специфично-проширеном значењу термина) литерарног, уз подвлачење питања да ли је компонента књижевног оно што га чини оним што јесте (Фохт 1976, Томашевић 1989), може се фокусирати на поступак карактерисања његовог настанка као ars combinatorie у равни текста, који начине и оруђа различитих дисциплина (уметности, филозофије, политике) укључује као своје саставне делове (Епштајн 1996), али се ова размишљања могу и сажимати у тврдњи да есеј није (ни) облик, већ стил заснован на паралелности темељног мисаоног рада и песничког сагледавања, односно на „имагинистичкој комбинаторици” као основи на којој се уобличава његов поступак (Хамбургер 1981, Томашевић 1989).

Нови слој питања о књижевном есеју, као непосредној теми ове расправе, отвара се у вези са његовим односом/преплитањем са књижевном критиком у основном значењу те речи - коментарисања и вредновања појединачних дела текуће књижевне продукције - али и у вези са трагањем за општијим својствима књижевне/књижевнокритичке мисли која се препознаје као основа низа размишљања унутар једног есејистичког опуса. У вези са првим питањем, установљена је начелна сродност есеја и импресионистичке критике (која је и настала у једном од периода његовог процвата), док се друго, за сваки посебан есејистички опус, разрешава формулисањем битних ставова на којима аутор, у различитим текстовима, заснива своја разматрања, чиме се формулише његова иманентна критичка/интерпретаторска поетика. Костићев укупан, не само књижевнокритички већ првенствено рад везан за најширу област књижевне мисли, који обухвата интерпретације одређених дела и поетике појединих опуса, најдиректније је везан за развијање и диференцијацију особеног есејистичког дискурса. Анализирање тог дискурса води нас ка синтетичком увиду у Костићево схватање књижевног стварања и књижевних вредности, као и у његове ставове о низу ванкњижевних феномена са којима они интерферирају.

Вероватно најинтригантнији пример есеја као „ероса језика” који собом производи нове поетске конфигурације и метафоричке аналогије предмета чијем је промишљању посвећен (Бензе 1976: 26), јесте управо „Ромео и Јулија". За разлику од једног ранијег покушаја ${ }^{1}$, овај рад ће тежити управо да

${ }^{1}$ У раду „Шекспиролошка мисао Лазе Костића” (Јовићевић 1991), утемељеном на анализи истог есеја, тежила сам да укажем на бит Костићеве интерпретације Шекспирових поступака и значења његове драме, и да истакнем да је њиме формулисано Костићево схватање Шекспирове поетике, на коме ће, имплицитно, темељити и своје доцније критичке/интерпретаторске осврте 
анализира текст есеја као такав, да укаже на функцију и евентуалне вредности његовог поетског и реторичког слоја, а нарочито на то како се преко њих разуђује почетна мисао/интерпретаторска тенденција аутора и надограђује иницијална тема.

У бити, истраживање треба да доведе до препознавања основних структурних и стилских особености текста који би, упркос обиму значајно ширем него што је за тај облик уобичајено, било најисправније назвати есејем. Објављен 1866. у десет наставака, од 36. до 45. броја, у тек покренутом новосадском часопису Матица, он је уистину посредовао неочекивано комплексан доживљај Шекспирове младалачке трагедије и њених вишеструких веза са различитим уметничким и животним појавама.

Полазећи од паралелности темељног мисаоног рада и песничког сагледавања материје, као законитости настанка есеја из које се у сваком појединачном случају рађа и његов карактеристичан облик, већ основни увид у карактеристике текста говори о јасној намери да се он оствари у високом песничком патосу и кроз особену „граматику” песничких слика, по којој je, у то време још млади Костић, већ постајао препознатљив.

Карактеристичан наслов његовог првог сегмента - „Једна глава из Шекспириве Библије" - не остаје само на нивоу општерихваћене метафоре из домена говорног стила, која уобичајено указује на неупитност значаја и вредности дела о коме се говори, већ постаје обликотворни принцип настајућег есеја: дат у форми библијске генезе, на коју упадљиво указује већ графичком организацијом, реторичким поступком и песничким сликама, овај први сегмент праћен је егзегезом (такође назначеном насловом наредног сегмента), у којој Костић истиче да му није доста да буде „еванђелиста” овом великом делу, већ да му „мора и апостолисати”, дакле не само тумачити већ и ширити, убеђивати у истинитост његове централне мисли. ${ }^{2}$

Тако ће ова два почетна поглавља, и интерпретаторска позиција која је у њима наглашена, постати центрипетална сила која окупља (не нужно и, у стандардном смислу, обједињује) низ фрагмената чија је почетна тачка тумачење одређених Шекспирових дела, готово увек у некој врсти контрастивне анализе у односу на Ромеа и Јулију.

Изриком одређујући, у следећем наставку, Шекспирову филозофију као антропоцентричну, Костић и даље, и управо на трагу таквог става, користи библијске метафоре да назначи полазиште свог разматрања. Представивши човека као ,један дух из груди творчеви дунут у прегршак блата”, Костић „дух” и „блато” уводи као метафоре сукобљених страсти у човеку, али и супротстављених светских и историјских сила чије је извориште у човековим

на Шекспирова дела. Та се студија, међутим, не бави стилском и структуралном анализом Костићевог текста и у највећој мери апстрахује његову целину (са бројним сегментима посвећеним другим темама) као контекст ставова и закључака које је изнео.

${ }^{2}$ Ова два, једина посебно насловљена поглавља, објављена су заједно, као нека врста диптиха, и сачињавају укупан текст првог од десет наставака у којима се есеј првобитно појавио. Овакав поступак на почетној тачки серијализације текста указује да је његов први део циљано уобличен тако да предодреди основни тон расправе и наговести приступ теми који би се најпрецизније могао назвати универзалистичким. 
ставовима и деловању. Тако ће овај концепт, у различитим конфигурацијама, бити основа за тумачење више драма и самих поетичких основа Шекспировог дела, за његово поређење са стваралаштвом других аутора или народа, али и разматрање историјских, политичких и културних питања који проистичу из исте врсте сукоба.

Потврђујући тезу да есејистички пише онај ко пише експериментишући - и то тако што свој предмет сагледава са разних страна и све из његовог суседства, што га на било који начин одређује, доводи с њим у комбинацију и тако изазива ново обликовање (Бензе 1976: 26) - Костић метафору „духа и блата" преноси на друга поља, која било каквом асоцијацијом могу да буду везана за започету апотеозу Шекспировог генија. Тако Шекспирово драмско уобличавање титанских страсти аналогијом доводи у везу са односом његове отаџбине Британије према океану, који она савлађује својом вољом и умом, док грађење фабуле драме на различитим страним предлошцима пореди са стварањем „насеобине” новог, шекспировског духа на страном тлу, као што његови земљаци стварају праве насеобине у колонијама или просто земљама у којима бораве.

Управо метафора заснована на паралелизму „насеобина” Шекспировог генија на предлошцима ранијих (страних) дела и енглеских насеобина у страним земљама, показује како Костић истим есејистичким дискурсом обухвата различите нивое текста, или чак на врло удаљене, а свакако ванлитерарне проблеме.

С једне стране, он овај феномен, у хуморном тону, разматра на површинском нивоу текста, показујући како у фабулу која се одвија у другом времену и поднебљу Шекспир уноси резоновање о проблемима карактеристичним за Енглеску његовог времена (у Ромеу и Јулији оно је уведено преко лика Меркуција, који се подсмева ширењу страних обичаја у народу, иако овај проблем није могао постојати у времену и месту збивања радње). С друге стране, улазећи у полемику око питања аутентичности Шекспирове инспирације у различитим делима, Костић истиче да су - као што су Британији најкорисније колоније биле „већ познате и већ донде [од Европљана] насељаване земље” - и Шекспировом духу најплодотворније тле представљале већ обрађиване приче, којих се после њега „нико не смеде машити”.

Будући да су изграђени на већ постојећим причама као предлошцима који представљају и надахнуће за стварање дела и „модел” за његову фабулацију, и Ромео и Јулија представљају једну од таквих „насеобина” Шекспировог духа, с тим што он својој „плодној Инђији” приступа другачије од својих актуелних земљака-колонизатора. Шекспир „не отима драгуље” из дела која је учинио обитавалиштем свог духа, већ их оставља где јесу, али их истовремено у својим драмама, у новом сјају, ставља на увид и дивљење целом човечанству. На тај начин, правећи „поређење по супротности” између Шекспировог књижевног поступка и ванкњижевне, историјске појаве, Костић указује на изузетност његове обраде већ постојећих сижеа, али и исказује став према геополитичким збивањима, што - на одређеном плану текста - постаје и доминирајући слој његових порука. 
Заокружујући одломак (дигресију?) о питањима „насеобина Шекспировог духа", односно Шекспировог односа према изворима и/или предлошцима на којима темељи своја дела - што, у зависности од средине у којој се одвијају поједине драме, поистовећује са њиховом блискошћу/страношћу егзистенцијалном и уметничком хабитусу аутора - Костић реторичким поентирањем у фокус расправе враћа њену иницијалну тему: Ромеа и Јулију као образац трагичке уметности и слику Шекспировог генија.

Но, враћајући се интерпретацији Ромеа и Јулије, Костић овој драми приступа из једне посебне перспективе. Иако уверен да њено постављање у, наизглед бизаран, комплементаран однос са Хамлетом доприноси разјашњавању одређених нивоа текста, он се не зауставља на психолошкој равни тумачења, на којој се овај сегмент текста начелно заснива и на којој су се у Костићево (а и потоње) време интерпретације Шекспирових дела неретко и окончавале. Уместо тога, он је чини основом за успостављање аналогија са другим, надређеним сферама и, у складу са романтичарском естетиком, значење драме универзализује представљајући конкретан драмски сукоб као слику (или посебну манифестацију) неког општег животног принципа, или чак божанског концепта:

Из отровног стакоцета Ромеовог и самртне ране на грудима Ђулијетиним диже се љубав да победи мржњу Монтекића и Капулетића, диже се дух да победи блато. [...] Ускршња глава јеванђелска и катастрофа у Ромеу и Јулији једна иста идеја у две претставе: она је претстава божанственија, ал' ова је приступнија, човечнија.

Тако ова особена контрастивна анализа Ромеа и Јулије и Хамлета, који су издвојени као срж Шекспировог опуса, крајњи исход ипак налази у првој од ових драма, „омиљеници” Лазе Костића: теза о борби и коегзитенцији „духа” и „блата” као обједињујућој унутрашњој теми Шекспирових трагедија, морала је, по Костићевом схватању, управо из ње бити најнепосредније изведена.

У недвосмисленом виду и праволинијској функцији, у њој се насловни јунаци јављају као носиоци првог, а њихове породице као носиоци другог принципа. Тежећи да метафору супротстављених сила, положених у корен људске и „светске” егзистенције, сагледа у пуној тематској и драматуршкој реализацији, Костић уводи нову, на исти начин поларизовану слику, са потпуним паралелизмом значења. Метафора „црне крви”, венозне, са извориштем у „утроби”, чији су носиоци Монтекији и Капулети, изједначена је са „блатом” и мржњом, док је „црвена крв”, артеријска, која настаје у плућима, у додиру са ваздухом и отвореним простором, а чији су носиоци Ромео и Јулија, идентична „духу” и начелу љубави.

Тежећи да драмску радњу доследно представи и њено значење универзализује у истом кључу фигуративног говора, Костић истрајава на антропоморфним алегоријским сликама. Само поље радње представљено је сликом срца у коме се сударају „облатовљен дух” и „одуховљено блато” - црна и црвена крв, завађене породице и трагични љубавници, а између раздвојених срчаних комора стоји „непробојна преграда, као суд божји, што дели добро 
од зла, мржњу од љубави, Монтекиће и Капулетиће од Ромеа и Јулије”. Борба „два начела васијонска” појављује се „у трусу бојишта, у куцању срца”, а метафора срца као бојишта супротстављених (васионских) сила довешће до проширивања ове слике елементима који омогућавају да се драмске појаве читају управо као алегорија њиховог деловања.

Срце као „двоклично семе”, дикотиледон „из кога је поникло дрво - човек”, јесте слика у којој Костић најпотпуније развија идеју о заплету Ромеа и Јулије као манифестацији васионских законитости у једном посебном збивању. Слика дрвета показује се као идеална фигурална представа Костићевих концепата, будући да својом вертикалом - од корења уроњеног у „блато”, односно „утробу” у којој се храни „црном крвљу”, до крошње и лишћа који, зачињући се посредством оплемењене, „црвене крви”, излазе у простор ваздуха и светла - успоставља потпуну паралелу са процесом „одуховљења блата" који је породичним лозама Монтекија и Капулета донео изданке чијим су настанком ушли у, њима непознату, сферу више егзиистенције.

Оваква метафорика широко засновано есејистичко излагање усмериће (и) ка једном универзалном поетичком исказу, којим ће расправа бити уведена у нову, завршну фазу:

То је почетак оног огромног борбенога кружења замисли творчеве, што га природне науке зову „прометом градива” и што доспева до свога вршка у животу срца човекова. Тај вриак живота васијонскога скупити параболским огледалом генија у једно огњиште, те представити га у малој ал' светлој слици гледајућим очима, то је задатак драмске уметности. (курзиви Т. Ј.)

На оваквим поетичким основама, и у истим сликама, Костић ће још једном - након њеног тумачења преко паралелизма са ускршњом главом Јеванђеља - дати виђење унутрашњег, универзалног смисла драмске радње Ромеа и Јулије. За њега, нема дилеме да се коначни смисао драме испољава у чину погибије љубавника, који „својим нераздељивим увеоком натруне земљу, начело мржње, и увеоком својим учине, што се ни цвету није могло, победе мржнину непомир [...] - оплоде земљу" (курзив Т. Ј.).

Овим указивањем на свеприсутност, али и на особен исход борбе чији је узрок „она васијонска двојина у драмству човекова живота, оно драмство живота у двојини васијонске природе", интерпретација Ромеа и Jулије суштински је довршена, али произвођење „нових поетских конфигурација предмета" ни изблиза није окончано.

Позивајући се на песнике (и књижевне јунаке) који су тежили да сагледају „прве почетке” ове непресушиве ускомешаности, Костић ће упоредити песништво Шекспира и Бајрона. Но, иако из ових редова провејава свест о комплексности Бајронове поезије, они су првенствено усмерени ка једном другачијем исказу: Бајрон, симбол слободарских прегнућа, супротстављен је актуелној Британији која је, облативши свој дух у колонијалној моћи и „грошићарском” поступању, уместо носиоца идеје слободе постала њен гушитељ и порицатељ. 
Не треба посебно наглашавати да се у овом делу као предмет расправе најпре отвара британски однос према „источном питању” и ослободилачким тежњама српског народа. Но, фокус се убрзо помера, а „османољубиви синови Албиона" су, више него што су прекоревани за своје држање, упозоравани на губљење супстанцијалности које је њиме покренуто.

Расправа о овом процесу, његовим одразима и импликацијама, преноси ce, још једном, на поље књижевности. Поричући било какву жељу за подршком „облатављене” Британије, Костић јој се ипак обраћа узвикивањем да иако „не требамо ваши стерлинга, требамо ваше Стернове, ако не требамо ваши булдога, требамо ваше Булвере, ако не требамо ваши чексова, требамо ваше Чекспире, ако не требамо ваши барона, требамо ваше Бајроне”. Ова типично костићевска игра речима, заснована на звучној подударности првих слогова у низу парова речи, којима се изнова указује на опозицију „блата” и „духа”, отвориће нови план књижевне расправе.

Елем ипак, ко велите, ипак ћемо приклонити поносно српско колено те молити у ваше милости да и наше пегазе пустите на те бесмртне паше елизејске, што на њима благује већ толико народа, толико језика?

Варате се. Те паше нису ваше. Ви сте то благо проиграли. [...]

И блато надвлада дух, и трбу надвлада груди, и океан као да већ надвлађује Британију, јер надвладаше стерлинзи Стернове, и булдози Булвере, и чексови Чекспире и барони надвладаше Бајроне.

И ти полубогови, заступници вечности народне, мораће оставити свој рођени Јеликон [...] мораће тражити себи насеобине, мораће, бежећи од свецкога тирана, наћи себи [...] ако не нов Јеликон, бар што више јеликончића.

На овом месту, при завршетку есеја, Костић своју расправу доводи у близину концепта на коме ће, након нешто више од једног века, бити утемељена постколонијална критика.

Иако припадник још неослобођеног народа, Костић се Британији као колонијалној сили не обраћа из позиције ьеног принудног поданика, већ напротив - из перспективе мислиоца и песника који се вољно изложио упливу великана њене културе, сматрајући да ова врста „колонијалног похода”, за разлику од свих других, доноси благодети онима који му се нађу на путу или се сами према њему отворе. Но тако наш песник долази у ситуацију необичне двострукости: с једне стране, под благодетним „колонијализмом” Шекспировог духа, открива комплексне вредности његовог дела и инспирацију за ново стваралаштво, а с друге стране, као припадник народа чијој слободи управо Британија, alter ego Шекспировог стваралачког хабитуса, поставља препреке, призива одбацивање њене улоге (стваралачке) парадигме и узора.

Међутим, за разлику од касније „праве” постколонијалне критике, Костић јој такав статус не оспорава a priori, већ зато што је - у ванкњижевним збивањима и процесима - изгубила духовну супстанцу из које су израстали њени великани. Стога се „пресељење Јеликона”, односно трансфер раније британске улоге на друга подручја, јавља као природна последица њене немогућности да убудуће изнедри сличне вредности. Позорница шекспировских страсти премешта се другде. 
А де би се могли приличније станити ти прогнани узори модерног Јеликона него у суседству класичног му имењака [...]? Де би се могао Дон Ђуан згодније населити него на врзишту сарајевски ашика и њиови ђулом окађени песнички уздисаја [...]? Де би се вољније одмарао величанствени зликовац, краљ Рикард, него што би у стару леглу Вукашинову?

Де би се, напослетку, могао прикладније пресадити онај зрачни изданак мржње и љубави [...] што се зове Ромео и Булијета, де би се могао дивније примити, него [...] у оној неувелој српској ал башти, у којој некада процвета Омер и Мерима, и по којој ће се разлегати [...] док је год света [...] она шекспирска реч слутеће Мејре:

„Мири ружа, Омерова душа”.

Поређење Ромеа и Јулије са „Омером и Меримом”, коме ће се Костић доцније у животу враћати, ${ }^{3}$ овде је развијено (као што је раније чињено при повлачењу паралеле између Шекспира и Бајрона) преко метафора биљног света: „мали једнодневни цветак” српске баладе, по слици љубави и уметничкој снази, сасвим је сличан „китњастом бокору пресађеном из веронски запуштени градина освајачком руком Шекспировом у енглески му парк, и тамо однегован и тамо сачуван и тамо овековечен".

Но, то поређење није развијено у компаративну анализу ових двају дела, већ служи као увод у још један, широки завршни осврт на најзначајнија својства књижевног поступка који је Ромеа и Јулију учинио обрасцем и узором драмске уметности. Ова особена стилска и драматуршка анализа такође је спроведена ослањањем на паралелу са појавама биљног света, које су узете за својеврсну алегорију елемената драмске радње и „израстања” драмског текста.

„Ал’ да видимо како (курзив Т. Ј.) је тај ђулак поникао из веронски леја”, каже Костић започињући завршни део свог есеја и уводећи Гетеову расправу Die Metamorphose der Pflanzen као „методолошко оруђе” за праћење и објашњавање структуре Ромеа и Јулије. Крећући од Гетеових речи како је раст биљке путовање ка светлости, Костић истиче да сваки развој - књижевног дела или живота у природи - мора ићи постепено: као што се „начело зрака поштује само у вапи биљског живота, у зеленилу”, док у семену биљке тек препознајемо ,радњу непречишћени земаљски сокова”, тако и у драмској радњи аутор на сцену најпре изводи „представнике мржњине”, ликове оковане ниским животом („црном крвљу” и „блатом”) да би тек потом, постепено, отворио простор за појаву „виших карактера” - у Ромеу и Јулији та линија води од слугу Капулетових у првој појави првог чина, преко слугу Монтекија, па Ромеовог пријатеља Бенволија и његових родитеља, да би се приказало земљиште које је отхранило биљку, односно да би се поставили основи и покренули механизми драмске радње. Тек тада створени су услови за увођење јунака драме, носилаца идеала, а непомирљивост њихове тежње са карактером околине јавља се као прави замајац збивања.

${ }^{3}$ Најзначајнији осврт на „Смрт Омера и Мериме” Костић ће, поново кроз поређење са Ромеом и Јулијом, дати десетак година доцније, у предавању „О женским карактерима у српској народној поезији” (1877). Тада ће ову паралелу знатно подробније елаборирати, поредећи „биће” љубави приказане у једном и другом делу (в. Крњевић 1980: 109-120). 
Остајући доследан схватању о радњи драме као манифестацији и одразу процеса у природи и космосу, Костић и њен даљи развој објашњава и приказује преко аналогије са растом биљке: као што биљка, док тежи расту у висину, пушта и грана корење у мраку и блату, тако и уздизање начела љубави у Ромеу и Јулији бива праћено све снажнијим радом начела и представника мржње. Препреке које она поставља љубави - закључно са најтежом, када „стари Капулет шаље младожењу Париса” - воде кулминацији сукоба и трагедији.

Обимом значајно дужи од претходних наставака, овај последњи, у коме се Костић на овако особен начин бави „економијом развитка” драме Ромео и Јулија, суштински не доноси много нових момената у њеном тумачењу, онаквом какво је конципирано још у почетним фазама расправе. Али, он овде изричито износи и образлаже свој, раније претежно имплицитан став о Ромеу и Јулији као пра-обрасцу трагедије. Аналогија развоја драме са растом и развојем биљке, како ће се показати, суштински је била усмерена на то да се покаже да (као што у Гетеовој замисли постоји пра-биљка) постоји и замисао пра-драме, чијој су суштини, од свих познатих творевина, најближи Ромео $u$ Јулија.

Цвет је увео. У најжешћим боловима највиши милина пао је увелак на земљу [...] и нагнојио је [...] остацима зрачнога живота свога. Љубав је обогатила крвницу јој мржњу благосиљјући је после најжешће мржњине напасти. [...]

Капулетићи и Монтекићи рукују се помирени над гробовима Ромеа и Ђулијете.

Васијонски проблем коегзистенције решен је. Одговорило се творцу на питање, што га је ставио створу своме у тренутку стварања, одговорио му је сам створ. Блато је одуховљено, ал' се и дух облатавио. Победник је, ал' је побеђен.

Шта је то учинило да баш ову драму Костић постави на то изузетно место? Без обзира на изражено дивљење њеној драматуршкој економији, разлог је очигледно другде: у Костићевом читању, Шекспирова поетска мисао је, трагајући за човековим одговором на „тајну постојања”, то чинила на трагу идеје о сукобу, укрштају и својеврсној хармонији супротстављених сила, пројављеној у трагичном расплету. Тако је у делу писца чији је култ одржавао Костић пронашао и антиципацију сопственог филозофског учења, а истовремено - стварајући неочекиване конфигурације првобитног предмета - из перспективе читања драме изнео опсервације низа наизглед удаљених појава.

\section{ЛИТЕРАТУРА}

Адорно (1955) 1996: Т. Адорно, Есеј о есеју, Београд: Реч, III/18, 61-63. Бензе 1976: M. Benze, O eseju i njegovoj prozi, Delo, XXII/5, 18-29.

Епштајн 1996: М. Епштајн, На раскршћу слике и појма. Есејизам у култури новог доба, Београд: Реч, III/18, 64-74. 
Јовићевић 1991: Т. Јовићевић, Шекспиролошка мисао Лазе Костића, у: Научни састанак слависта у Вукове дане 21/1, Београд: Међународни славистички центар, 119-126.

Крњевић 1980: H. Krnjević, Živi palimpsesti ili o usmenoj poeziji, Beograd: Nolit. Лукач (1910) 1973: Đ. Lukač, O suštini i obliku eseja, u: Duša i oblici, Beograd: Nolit, 1973, 33-55.

Томашевић 1989: Б. Томашевић, Есеј као парадигма интертекстуалности, Нови Сад: Летопис Матице српске, CLXV/6, 723-734.

Фохт 1976: I. Foht, Esej kao protuteža filozofskom sistemu, Beograd: Delo, XXII/5, 30-39.

Хамбургер 1981: M. Hamburger, Essay über den Essay, Literarische Erfahrungen, http://docplayer.org/36441-Michael-hamburger-essay-ueber-den-essay.html, 20.11.2016.

Tatjana N. Jovićević

ESSAYISTIC DISCOURSE AND THE (CRITICAL) LITERARY THOUGHT OF LAZA KOSTIĆ

(Summary)

The paper is analyzing Kostić's disputation on Romeo and Juliet (1866), firstly taking into consideration the aspects defining the text as an essay. Taking that essay is mainly defined by its discourse, it explores the inherent relations beetwen the interpreting attitude and the metaphors used to disclose the ultimate meaning of Shakespeare's tragedy. Since the same metaphors are used to denote non-literar (historical/political) processes, Kostić incessantly produces different "poetical configurations" of the initial subject of his essay, structuring the text whithin which different levels of literar and non-literar reality are mutually interpreted from the sole point of view. Certain scenes and statements in the drama are seen as the particular manifestation of the generic motion of nature and the "law of Universe". On another level, Kostić compares later approaches to the themes generally akin to the one in Romeo and Juliet: Byron's ironical deconstruction of the myth of eternal love vis-a-vis, entirely Shakesperean concept of the Serbian folk ballade Omer and Merima. The latest title arouse the question of relations among ,central"/"model” literatures and the literatures of other cultures, which in some aspects appears as an anticipation of modern postcolonial studies. 